${ }^{1}$ П.А. Бычкова, ${ }^{1,2}$ Е.В. Рахилина, ${ }^{1}$ Е.А. Слепак

${ }^{1}$ НИУ «Высшая шккола экономики»,

${ }^{2}$ Институт русского языка им. В. В. Виноградова РАН

(Россия, Москва)

polyatomson@gmail.com,rakhilina@gmail.com,janenikel16@gmail.com

\title{
ДИСКУРСИВНЫЕ ФОРМУЛЫ, ПОЛИСЕМИЯ И ЖЕСТОВОЕ МАРКИРОВАНИЕ*
}

Лене Гришиной

Да ну вас, да ну вас, да ну вас (Закат, предпоследний, погас). Житейская глупость и грубость Уже не касаются нас.

Касаются - влажные ветки Твоей побледневщей щеки. Заботы, как бурые белки, Умчались по веткам, легки.

И. В. Чиннов. «Да ну вас, да ну вас, да ну вас...» (1978)

В статье представлено обсуждение маркирования семантики особых конструкций разговорной речи - дискурсивных формул. Вопрос о специальных средствах маркирования значения возникает в связи со свойством дискурсивных формул выступать в качестве законченных фиксированных реплик, без контекста внутри высказывания говорящего, и одновременно присущей им способности быть полисемичными. На примере русской многозначной дискурсивной формулы Да ну! показывается, как в случае полисемии таких единиц может происходить различение значений: помимо просодии смыслоразличительную функцию выполняет жестикуляция, сопровождающая высказывание. В тексте статьи приводится классификация контекстов употребления формулы Да ну! и выделяются пять основных ее значений: удивление, удивление-недоверие, девалоризация собеседника,

\footnotetext{
${ }^{1}$ Исследование выполнено при поддержке гранта РНФ № 16-18-02071
} 
девалоризация речевого акта собеседника и «положительная» девалоризация опасения. Коротко освещаются предполагаемый путь конструкционализации формулы и развития каждого из значений. Далее производится количественный анализ жестикуляции, встретившейся при употреблениях формулы в Мультимедийном корпусе русского языка, основанный на разметке всех движений говорящего в момент произнесения Да ну!. Выявляется корреляция между выделенными значениями и набором определенных жестов, что позволяет с одной стороны выстроить карту смежности существующих значений формулы, а с другой стороны получить представление о семантике свойственных разным значениям жестов.

Ключевые слова: грамматика конструкций, дискурсивные формулы, жестикуляция, полисемия, прагматика

\section{1. Введение}

Замысел этого исследования возник при работе над базой данных по русским конструкциям «Русский конструктикон», которая строится в рамках совместного проекта Школы лингвистики НИУ ВШЭ, Арктического университета Тромсе и университета Гётеборга. База «Русский конструктикон» аккумулирует неоднословные последовательности языковых единиц, которые в русском языке некомпозициональны, так что их семантика, так же как и у знаменитой английской конструкции с letalone [Fillmore 1988], не складывается из семантики составляющих ее фрагментов. Важное свойство конструкций в том, что в их составе есть свободные слоты (переменные), которые позволяют конструкции встраиваться во внешний контекст, изменяться, изменять свойства заполняющих слоты единиц и т. д. [Рахилина, Кузнецова 2010]. Поэтому одна из задач базы «Русский конструктикон»описать слоты каждой конструкции, разметить соответствующие им семантикосинтаксические роли и обозначить ограничения на их заполнение.

К настоящему времени база насчитывает уже около 700 конструкций с разметкой, толкованиями, примерами, а для части конструкций - переводами на английский и норвежский [описание базы см.: Jandaetal. 2018]. Предполагается, что в результате в «Русском конструктиконе» будут собраны все русские конструкции - как классические, с фиксированными лексическими вставками, типа| (1) или нетривиальным управлением, как (2), так и чисто грамматические, то есть состоящие из слотов с заданной грамматической информацией, ср.ґ(3).

(1) a/так что насчет XP? (а как насчет пятницы?)

(2) NP-Acc звать NP-Ins /Nom (мальчика звать Юрой)

(3) NP-Dat (не) VP-ся (мне не спится)

База «Русский конструктикон» решает важную практическую задачу, — ведь полного словаря конструкций пока нет ни для одного языка. Одновременно она выполняет и задачу теоретическую, связанную с уточнением границ понятия «конструкция»: если действительно удастся составить полный список конструкций 
хотя бы для одного языка, среди них, помимо прототипических, наверняка обнаружатся и не вполне стандартные, периферийные и пограничные, имеющие нетривиальные свойства формы или семантики.

Один такой класс уже выделен, и он будет объектом описания в нашей статье. Это частный тип конструкций, который нуждается в особом формате представления в базе: изолированные составные реплики в диалоге, имеющие фиксированную форму и синтаксически равные предложению, типа: Kто бы говорил! Что ты наделал! Ещзе был! и подобные. Вслед за Ч. Филлмором [Fillmore 1984] мы назвали этот класс конструкций дискурсивньлми формулами (discourse formulas). Дискурсивные формулы очень близки конструкциям: они неоднословны и всегда крайне идиоматичны. Особенность их в том, что они, в отличие от канонических конструкций, как правило, вовсе не имеют слотов. Это свойство вызвано их синтаксической изолированностью и неизменной, так сказать формульной, природой: они представляют собой диалоговые шаблоны, которые запоминаются и воспроизводятся говорящим как есть. Понятно, что такие формулы составляют важный пласт разговорного языка, а значит, должны быть собраны и полностью описаны. Эта проблема осознается лингвистическим сообеестом, и похожие классы единиц разного объема и под разными названиями начинают постепенно вводиться в лингвистический оборот (cp. routines [Coulmas 1981; Aijmer 1996], коммуникативы [Шаронов 1996; Шаронов 2009] и др.).

Понятно, что для их описания требуются специальные исследования и специальные форматы представления данных, так что, например, в «Русском конструктиконе» этот тип конструкций выглядят как крайне периферийный, не похожий на прототип. Главное, что здесь упускает действующий формат «Русского конструктикона», - это роль жестикуляции и интонации. Именно на этой задаче мы остановимся подробнее. Чтобы понять ее значимость, мы специально выбрали здесь для анализа многозначную формулу Да ну!, имея в виду описать семантику ее основных употреблений и их корреляцию с сопутствующей жестикуляцией ${ }^{1}$.

Главным источником наших данных будет Мультимедийный подкорпус НКРЯ (МУРКО), собранный и сконструированный Леной (Еленой Александровной) Гришиной, и ее книга [Гришина 2017], в которой представлена разработанная ею методика анализа материала МУРКО².

Лене Гришиной и ее беспрецедентному проекту мы и посвящаем эту статью.

\footnotetext{
${ }^{1}$ Как мы только что сказали, в разрешении многозначности дискурсивных формул может участвовать и интонация. Это обстоятельство нам важно, но для данной статьи - только как фон для описания жестикуляции, так что сведения об интонации будут даны лишь в самом общем виде [Дурягин, Рахилина 2019].

2 Заметим, что и сама Е. А. Гришина когда-то решала похожую на нашу задачу описания многозначных дискурсивных маркеров $A$ ! и $O$ ! и их жестовых параметров [Гришина 2009; 2010].
} 


\section{2. Да ну: общая информащия}

Если судить по материалам НКРЯ, да ну является довольно частотной дискурсивной формулой: в основном корпусе нашлось 852 ее вхождения. Очевидно, что она является разговорной: в более формальном газетном корпусе, примерно равном по объему основному, имеется только 154 вхождения, в поэтическом корпусе, который, как правило, отражает более старшую норму и редко - современную разговорную [Рахилина, Плунгян 2012], встретилось всего 15 вхождений, а вот в устных корпусах таких вхождений много больше: в устном подкорпусе НКРЯ 471, а в МУРКО 291. Диаграмма (рис.1), которая отражает соотношение встречаемости формулы Да ну! в разных подкорпусах НКРЯ, подтверждает ее разговорный характер.

По данным НКРЯ, впервые да ну как стабильная конфигурация стало употребляться в начале XIX в., - но в уже устаревшем сейчас значении ускорения, ср. (14)|и (5):

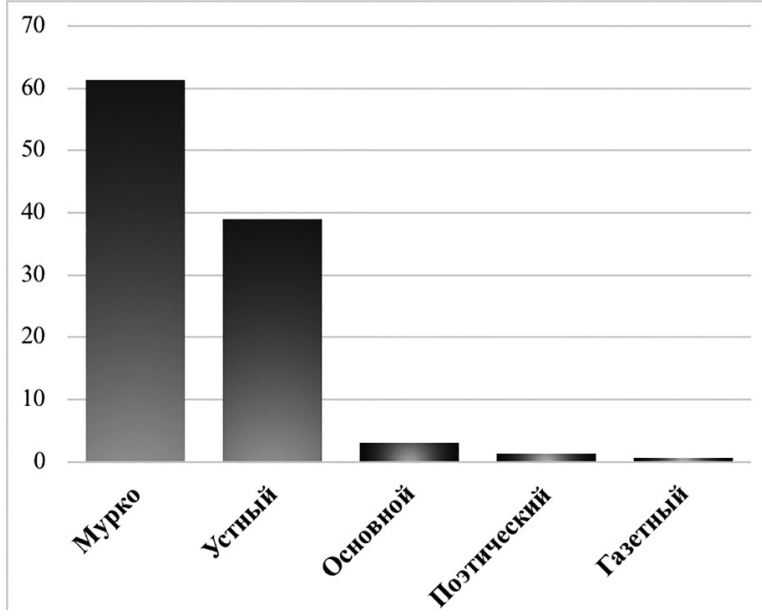

Рис. 1. Частотность да ну в подкорпусах НКРЯ, i.p.m.

(4) Как ни лестно было для меня это приглашение, однако ж я долго отговаривался, извиняясь тем, что, не зная стихов, невозможно хорошо читать ux, потому что легко дать им противосмыслленную интонащию, но Гаврила Романович с нетерпением сказал: «Э, да ну, братеи, читай!» (= 'скорей читай’) [С.П. Жихарев. Записки современника (1806-1809)].

(5) Да ну, брат, поскорее! Как ты копаешься! [Н. В. Гоголь. Женитьба (18331842)].

Такие употребления почти исчезли - в современных текстах они заменились на ну же, ну давай, однако встречаются до сих пор, особенно в стилизациях, как речь эмигранта из романа Набокова (6) в переводе С. Ильина:

- Чудно, Кармен, - ответила Долли и, обернувшись ко мне, продолжала по-русски. - По-моему, тебе не мешает выпить прямо сейчас. Да ну, пойдем же! И Бога ради, оставь ты здесь пиджак и жилет. [Владимир Набоков. Смотри на арлекинов! (С. Ильин, 1999)].

Ср. здесь исходный англоязычный текст самого Набокова в (7), ясно указывающий на то, что выбранный эквивалент передает ровно этот уже устаревший смысл: 
(7) "Righto, Carmen," replied Dolly, and turning to me continued in Russian: "I think you need that drink right away. Oh, come along! And for God's sake leave that jacket and waistcoat here." [Vladimir Nabokov. Look at the harlequins! (1974)].

Употребления (4)-(6) хорошо отражают исходную для да ну точку процесса, который по аналогии с грамматикализаиией, то есть превращением лексемы в грамматический маркер, - называют конструкционализацией [Traugott, Trousdale 2013] - превращением семантически прозрачной последовательности лексических единиц в некомпозициональную конструкцию. Действительно, в исходном значении, которое иллюстрируется (4)-(6), да ну выступает как синоним ну (исходно - междометие, сопровождающее подстегивание лошади, ср. глагол понукать) с усиливающим его $\partial a$ : во всех этих контекстах $\partial a$ можно легко опустить. Таким образом, исходно, причем еще в начале XIX в., да ну представляло собой композициональную последовательность двух частиц $\partial a+н y$. Теперь это некомпозициональная формула, развившая несколько значений - разных типов удивления и отрицания, к описанию которых мы переходим в следующих разделах.

\section{Примечание}

Косвенным свидетельством некомпозициональности $\partial а$ ну можно было бы считать дискурсивную формулуну $\partial а$, которая состоит из тех же, но собранных в другом порядке компонентов и обладает другим набором значений, - в основном согласия/подтверждения. Скорее всего, эти формулы просто совпали. Действительно, ну да восходит не к $н y$, а к $\partial а$-согласия/подтверждения, интенсифицированному ну, которое добавляет ему идею ожидаемого, естественного следствия (8).

(8) Ванька. $<\ldots>$ Ведь ты знаешь, барин мой звал ваших сюда на завтрак. Даша. Нy, да! мы затем и выехали. [И. А. Крылов. Пирог (1799-1801)] Дополнительно о ну да см. [Кобозева и др. 2018].

\section{3. Да ну: природа многозначности}

Как мы уже говорили, основным материалом нашего исследования был Мультимедийный корпус русского языка. В нем было отобрано 190 видеофрагментов, содержащих формулу $\partial a$ ну,которая отделенавосклицательным/вопросительным знаком, точкой, запятой или паузой. Все эти фрагменты были размечены: каждому клипу был приписан тег, соответствующий значению конструкции. Однако детальная семантическая разметка формул связана с трудностями: ведь прототипически дискурсивные формулы представляют собой отдельные предложения, и у них нет ближайшего контекста, который, как это обычно бывает, различался бы лексико-синтаксически и противопоставлял разные группы употреблений.

В поисках поверхностных маркеров семантических противопоставлений мы размечали жесты: движения рук, головы, корпуса, мимику и ориентацию взгляда - по тем фрагментам, на которых жестикуляция была хорошо видна, всего их 
оказалось 78. Кроме того, клипы просматривались в программе PRAAT для определения интонационного контура. Косвенным способом проверки правильности деления на группы значений для нас были русские квазисинонимы формулы, а также ее переводные эквиваленты - в основном это были переводы на английский, подобранные по параллельному корпусу НКРЯ.

Таким образом, семантическая классификация принятых здесь значений да ну верифицировалась трояко: типологически, то есть переводом на другой или другие языки, а также типом жестикуляции и интонации ${ }^{3}$.

С большой долей очевидности употребления да ну делятся на две крупные семантические группы, которые мы условно назвали УДИВЛЕНИЕ (Да ну? Неужели?), как в (9), и ДЕВАЛОРИЗАЦИЯ - разновидность глубинного отрицания [Гришина 2017: 448], как в (10).

(9) А: Эй, молодой человек, где ваш приятель?

B: А зачем?

А: Он увёл нашу Машу туда.

В: Да ну?! Вот молодец!

[Иван Пырьев, Николай Погодин. Кубанские казаки, к/ф (1949)]

(10) А: Надо в библиотеку сгонять.

Б: Да ну!!! Потом сгоняем.

[Праздный разговор // Из материалов Ульяновского университета, 2007]

Эти две группы должны хорошо различаться интонационно: русскому удивлению/ восхищению свойственна комбинация «восходящий + нисходящий акцент» $\left(\mathrm{MH}^{*}+\right.$ HL*) — [Князев, Пожарицкая 2011: 174; Касаткин 2007: 260], — тогда как контекстам девалоризации присущ нисходящий акцент HL* [Дурягин, Рахилина 2019].

\section{Примечание}

В НКРЯ нашлись переходные примеры, на основе которых можно восстановить семантический сдвиг, превративший маркер усиленного и желаемого ускорения в каждое из этих значений. Дело в том, что самым частотным и естественным контекстом для да ну-ускорения является (помимо исходного - ускорения движения) ускорение речи, когда говорящий торопит собеседника сообщить ему новую интересную информацию. В примере (11) середины XIX в. в этой функции сначала выступает просто ну, а потом, после того как уже получена некоторая новая информация, но все еще требуется новая, и да ну. В таком случае отделить семантику понукания (требования следующей порции информации) от семантики удивления (вызванного новыми сведениями) очень трудно, и с этой точки зрения (11) представляет промежуточный, переходный случай:

3 Заметим, что разные диагностики не обязательно действуют синхронно - нас прежде всего будет интересовать роль жестикуляции. 
(11) - Да пономарева-то могила... и того!

$-\boldsymbol{H} \boldsymbol{y} !$

- И рассыпалась.

-Дану!

- Обвалилась; дождем ее, знаешь, полило, она и провалилась.

[Н. С. Лесков. Засуха (1862)]

Вторая траектория семантического развития да ну-ускорения связана с тем, что говорящий торопит собеседника перейти к разговору на интересующую его тему (или действию, как в примере (12)), а тот продолжает говорить о своем. Одновременно с желанием, чтобы собеседник скорее выполнил то, что от него требуется, говорящий испытывает раздражение по отношению к нему и к ситуации в целом. Это - потенциальный источник семантики девалоризации:

(12) Ну, что там? - заключает хозяйка, направляясь к двери и ведя за руку сына; но сделав два шага, она останавливается и продолжает, обернувиись к гостю боком: - Так я его тогда урезала - страсть! <...> «Это, говорю, подло, бесчестно, говорю, - четыре иелковых». -Да ну, иди, что ль, кней, - перебивает муж. - Пойду <..> [Г. И. Успенский. Гость $(1865)]$

Дальнейшие наши исследования показывают, что противопоставления более дробны: в русском различается по крайней мере два типа удивления и несколько разных типов девалоризации. В свете данных МУРКО нам важно, что об этом свидетельствуют и жестовые диагностики.

\section{4. Удивление}

\section{1. Собственно удивление}

Удивление возникает как эмоция говорящего в ответ на новую информацию именно ее маркирует конструкция $\partial а н$, которой в этом случае можно приписать следующее примерное толкование:

'Говорящий не знал о том, что Р, собеседник ему сообщает, что Р. Неожиданность информации вызывает эмоцию удивления, говорящий принимает Р к сведению’.

Квазисинонимами к да ну в этих контекстах выступают такие реплики, как: $H y$ и ну! Да ты что? Что вы говорите? Неужели? Серьезно? Переводные эквиваленты, в сущности, тоже являются квазисинонимами, но в несколько более широком, типологическом смысле [Рахилина, Резникова 2013]. В английском это часто $O h, m y !$ или просто Oh!, а также так называемые tag questions, cp. примеры (13)|и (14) по параллельному корпусу: контекст показывает, что в обоих случаях говорящий сталкивается с новой для него информацией, удивлен ею и принимает ее как данное. Показателен последний пример, который демонстрирует нетождественность (по крайней мере для 60-х гг. ХХ в.) русского $O$ ! (в отличие от формально тождественного ему английского $O h !)$ группе маркеров удивления, которой принадлежит да $н y$ : 
(13) Conventions or not, but it was my birthday too, small difference of sixteen years, that's all. Oh my! Congratulations. [Vladimir Nabokov. Pale Fire (1962)].

Условность или нет, но это был также день моего рождения - каких-нибудь шестнадизать лет разницьь, вот и все. Да ну? Поздравляю вас. [Владимир Набоков. Бледный огонь (Вера Набокова, 1983)].

(14) “No, Eeyore, I don't." "It means Learning, it means Education, it means all the things that you and Pooh haven't got. That's what A means." "Oh," said Piglet again. "I mean, does it?" he explained quickly. [A. A. Milne. The House at Pooh Corner (1928)].

- Нет, Иа, не знаю. - Оно означает Учение, оно означает Образование, Науки и тому подобные вещчи, о которых ни Пух, ни ты не имеете понятия. Вот что означает A. - О! - снова сказал Пятачок. - Я хотел сказать «Да ну?» — поспешно пояснил он. [Алан Александр Милн. Дом на Пуховой Опушке (Б. Заходер, 1960)].

Как мы увидим дальше, хорошим поверхностным маркером этого класса употреблений да ну (как и следующих) оказывается жестикуляция: такая эмоция сопровождается характерными жестами и мимикой: корпус подается вперед, брови подняты, взгляд на собеседнике либо переходит (в терминологии Е. А. Гришиной) в зону коммуникации [Гришина 2017: 491] $]^{4}$.

\section{2. Удивление \& отрицание (неверие)}

Семантическая разметка формул часто дает промежуточные классы с комбинацией разных типов эмоций-реакций. В частности, одна и та же эмоция может фигурировать как в да-репликах, так и в нет-репликах, или положительных и отрицательных ответах. Таким образом, появление в разметке двух типов удивления вполне предсказуемо: если первое кодирует ситуацию, в которой говорящий принимает новую для него информацию, то должно быть второе, где говорящий по тем или иным причинам ставит ее под сомнение, не верит в сказанное:

Костя почему-то поражен, и почему-то не верится ему, что у Майки была любовь с Женей: -Да ну, не может быть! - Было, - вздыхает мать. [В.Ф. Панова. Конспект романа (1965)].

Ср. также аналогичный пример начала XX в.:

(16) Tы пойдешь, Данило, а я над вами воеводою! -Да ну?-недоверчиво спросил Прилуков. [А.Е. Зарин. Кровавый пир (1901)]

4 Удивление может быть не только неподдельным, но и нарочитым, выражающим иронию говорящего по отношению к собеседнику и его новости. Для иронических контекстов жесты и мимика удивления не так релевантны, однако направление взгляда сохраняется и добавляется наклон головы, который в [Гришина 2017: 457, 458] служит одним из признаков отрицания. 
Этот подтип удивления, который мы условно назвали НЕВЕРИЕ, можно истолковать примерно так:

'Говорящий не знал о том, что Р, собеседник ему сообщает, что Р. Неожиданность информации вызывает эмоцию удивления, говорящий не готов считать Р достоверным'.

Как видим, дополнительная семантика прямо противопоставляет этот тип удивления обычному. Квазисиноним Не может быть! не передает этого противопоставления в полной мере, потому что в принципе он применим и к каким-то контекстам первого типа. Чтобы более точно отразить нужную семантику, здесь нужно значительно нарушить баланс удивления и отрицания в сторону отрицания, ср., например: Никогда не поверю! ${ }^{5}$ Не случайно переводчики усматривают у этого типа да ну прямую связь с отрицанием, см. No! как его эквивалент в примере (17). В другом переводе с английского (18) да ну тоже возникает как маркер полного недоверия к сказанному собеседником, лишенного каких-либо положительных эмоций.

(17) He said he saw us with Eddie Harris at Martin's last night. "No!" They both giggled. [Theodore Dreiser. Sister Carrie (1900)].

- Говорит, будто видел меня с Эдди Гаррисом у «Мартина». — Да ну? Девушки захихикали. [Теодор Драйзер. Сестра Керри (М. Волосов, 1927)]

$<\ldots>$ "we married a gen'l'm'n twice your size, last Monday." "Did you, though?" "To be sure, we did, "says the touter $<\ldots>$ [Charles Dickens. The Posthumous Papers of the Pickwick Club (1836-1837)]

$<\ldots>$ в понедельник мы женили джентльмена вдвое против вас объемистей». - «Да ну? Будьте увереньл, женили, - говорит тот <..> [Чарльз Диккенс. Посмертные записки Пиквикского клуба (А. В. Кривцова, Е. Л. Ланн, 1933)]

Понятно, что никаких стандартных специальных контекстных маркеров для обозначения положительного/отрицательного отношения говорящего к новой информации нет, однако интонационный контур удивления-неверия (L*, cм. подробнее [Дурягин, Рахилина 2019]) отделяет его от обычного удивления и отождествляет со значениями девалоризации. Зато мимически и жестово эти типы контекстов

${ }^{5} \mathrm{Cp}$. также иронический вопрос Да ладно?, который имеет именно значение удивления-неверия (А) и невозможен в контексте простого удивления, как в (Б).

(А) - Ну как пирожки? - Не хочу тебя расстраивать, но, по-моему, они испорченные.

- Да ладно? < ..> Да не, ну я бы сразу почувствовал. [Дмитрий Дьяченко и др. День радио, $\kappa / \phi(2008)]$

(Б) Вот что означает А. - О! - снова сказал Пятачок. — Я хотел сказать «Да ну/*Да ладно?» — поспешно пояснил он. [Алан Александр Милн. Дом на Пуховой Опушке (Б. Заходер, 1960)]

Исходное значение этой формулы совершенно иное, чем у да ну: его можно было бы описать как ‘безразличное согласие', ср. (В). Однако в целом кластер значений да ладно очень близок к $а$ ну.

(В) ...Мстительные мероприятия отключающих провайдеров вызвали скорее снисходительную $\kappa$ «Дождю» реакичю - «Да ладно, черт с ним». [Максим Соколов. Дубина общественного возмущения // Известия. 2014. 30 янв.] 
и противопоставлены, и отделены от других. Так, в случае неверия брови могут быть нахмурены, а плечи подняты (пожимание плечами) — и эта мимика/жестикуляция для обычного удивления не характерна. А жест «махнуть рукой», свойственный в той или иной мере всем остальным классам девалоризации, отсутствует и в удивлении, и в удивлении-недоверии.

\section{5. Девалоризация}

Принципиально другое значение формулы да ну возникает при смене типа стимульной реплики. До сих пор мы обсуждали контексты, в которых речевым стимулом для говорящего было утверждение собеседника, содержащее новую информацию. Эту информацию он либо принимал, либо обесценивал. Между тем реакция девалоризации может возникать и в ответ на речевые стимулы других типов, относиться к разным параметрам ситуации и даже иметь разную степень негативности.

В отношении да ну мы предлагаем различать:

- девалоризацию предложения и отказ выполнить предлагаемое;

- девалоризацию решения, о котором сообщает собеседник (сопровождается отрицательной оценкой самого собеседника). Ср. Да ну тебя!;

- девалоризацию самого речевого акта высказывания собеседника;

- девалоризацию негативного суждения 6 .

Эти четыре типа употреблений да ну! мы рассмотрим в 5.1-5.4.

\section{1. Отказы}

Формула да ну как ответ на предложения, приглашения или советы не может выражать удивление - или только лишь удивление: естественным ответом на стимулы такого рода может быть либо положительная, либо отрицательная реакция: или согласие, или отказ. Для исходной семантики да ну (например, в свете семантики удивления-неверия, которая относится к группе отрицательных значений) более естественным выглядит развитие семантики отказа.

Предложение собеседника может быть прямое (10) или косвенное (19). Ответ да ну! здесь означает его девалоризацию и нежелание выполнить предлагаемое:

(19) [Сергей] С днем рождения тебя́!

[Люда] Спасибо, Сережка! А почему́ ть́́ не захотел прийти́ вечером, когда́ соберутся все́ гости?

[Сергей] Да ну! Придут одни́ твои́ родственники. О чем мьи́ с ними будем говорить? [Карен Шахназаров и др. Исчезнувшая империя, к/ф (2008)].

${ }^{6}$ В просторечном и диалектном дискурсе можно найти и другие употребления $\partial а$ ну - например, в качестве отрицательного ответа на вопрос, как в (А).

(А) Интервьюер: А за хмелем с мешками ходили?

Респондент, 1940 г.р.: Да ну, с мешками! Да сумочки возьмем да в сум... сколько там его надо. А он же легкий. [Корпус говора села Роговатое]. 
Частая разновидность этого случая - когда в первой части обсуждается лицо или объект как некий, возможно, подходящий вариант для некоторой ситуации Р (эту часть можно рассматривать как вариант предложения разделить оценку обсуждаемого лица), а во второй он девалоризируется: оценивается говорящим как неприемлемый и неудачный (20):

(20) [Даша, жен, 19] Ой, все, разонравился мне Пама.

[Женя, жен, 19] Как? Классный ведь парень!

[Даша, жен, 19] Да ну! Зануда он!

[Разговор знакомых // Из материалов Ульяновского университета, 2007].

\section{2. Девалоризация собеседника}

Такого типа реплики - с отрицательной оценкой собеседника - засвидетельствованы еще в 60 -е гг. XIX в. (см. 21) и до сих пор остаются достаточно частотными в разговорной речи.

(21) Пожалуйте, сударыня, Татьяна Марковна, ручку! Он схватил старушку за руку, из которой выскочил и покатился по полу серебряный рубль, приготовленный бабушкой, чтоб послать к Ватрухину за мадерой. - Да ну, бог с тобой, какой ты беспокойный: сидел бы смирно! - с досадой сказала бабушка. [И.А. Гончаров. Обрыв (1869)].

Наиболее характерным прагматическим контекстом для них, по нашим данным, является «трехчастный» (то есть состоящий из трех связанных между собой реплик) диалог, в котором первая реплика - это просьба или поручение говорящего, а вторая принадлежит его собеседнику и дает прямое или косвенное свидетельство его некооперативного поведения. Оно и служит наиболее частотной и естественной причиной раздражения или разочарования говорящего — в ситуации в целом и собеседнике в частности, ср:

[Говорящий предлагает/просит] - [отказ собеседника] - [говорящий недоволен, раздражен]

[Говорящий дал поручение $]-$ [собеседник не выполнил] - [говорящий разочарован]

A: Кисет-то мой принесла?

Б: Ой, забыла, миленький Федот Евграфыч, забыла.

А: Да ну! Да ладно уж! Махорка имеется. Спасибо сидр мой не забыли.

[Станислав Ростоцкий, Борис Васильев. ...А зори здесь тихие, к/ф (1972)].

С еще большей очевидностью оценка собеседника присутствует в варианте этой дискурсивной формулы, содержащей местоимение: Да ну тебя/ваc/ezo/ee/ux!, который семантически тождествен именно такому девалюативному употреблению Да ну! В принципе во всех случаях местоимение можно добавить или убрать без изменения смысла - это обстоятельство мы учитывали при поиске переводных 
эквивалентов, а их непросто найти, во всяком случае в английском. Заметим, что степень недовольства собеседником и раздражения против него недостаточна для того, чтобы заменить да ну! на прямую агрессию и ругань, адресованную непосредственно участнику диалога. Создается впечатление, что говорящий все-таки не перекладывает всю вину за провал своего плана на собеседника, а частично списывает ее за счет неудачно сложившихся обстоятельств. Поэтому даже в переводах на английский, в котором нет подходящей формулы, встречающиеся в качестве эквивалентов маркеры агрессии не имеют конкретного адресата:

(23) No, sah, I doan' want no sichdoin's. “Blame it, can't you TRY? I only WANT you to try - you needn't keep it up if it don't work. " [Mark Twain. The Adventures of Huckleberry Finn (1884)].

Нет, сэр, ничего этого я не желаю. - Да ну тебя, неужели хоть попробовать не можешь? Ть только попробуй, а не выйдет, возьмешь и бросишь. [Марк Твен. Приключения Гекльберри Финна (Н. Дарузес, 1950)].

"You can't stay here. Why, with nobody to take care of you, you'd starve." Grampa cried, "Goddamn it, I'maol' man, but I can still take care a myself." [John Steinbeck. The Grapes of Wrath (1939)].

Как ты будешь жить? Кто о тебе позаботится? Ведь с голоду умрешь! Дед закричал: - Да ну вас всех! Я хоть и старик, а сумею сам о себе позаботиться. [Джон Стейнбек. Гроздья гнева (Н. Волжина, 1940)]

Другой характерный вариант переводного эквивалента для да ну-девалоризации с акцентом на собеседнике (или да ну $P R O N_{A C C}$ ) - междометия, как если бы говорящему от возмущения и разочарования просто нечего было сказать:

"I should have thought." Mr. Lorry began. "Pooh!You'd have thought!” said Miss Pross <...> [Charles Dickens. The Tale of two Cities (1859)].

Мне кажется...- - начал было мистер Лорри. - Да ну вас, что это вам еще кажется! - перебила его мисс Просс <... > [Чарлз Диккенс. Повесть о двух городах (С. Я. Бобров, М.П. Богословская, 1950-1960)].

Зато в самом русском есть квазисинонимы к этому типу девалоризации, которые заслуживают внимания, ср. Иди к черту! Механизм девалоризации, который они реализуют, состоит в исключении собеседника из так называемой «личной сферы говорящего» [Апресян 1986] - это именно тот тип манипуляции («наказания» собеседника), который в ответ на некооперативность маркируется Да ну (синонимичное Да ну $\left.P R O N_{A C C}\right)$.

Замечательно, что он иконично маркируется в русской жестикуляции и мимике: помимо оценочного «нахмурить брови» и движения взгляда от собеседника (по Гришиной, это маркеры отрицания и дистанцирования), ему соответствуют жесты «отвернуться от собеседника» и «махнуть рукой», который выражает досаду и одновременно служит эмблемой прощания и расставания (специалисты относят его к так называемой Away Gestures Family — см. [Bressem,Müller 2014]). 


\section{3. Девалоризация речевого акта}

Этот класс употреблений $\partial а$ ну реагирует не на суть сказанного собеседником - он претендует на то, чтобы дезавуировать сам речевой акт, указав на его неуместность. Понятно, что не любой речевой акт можно отменить, - самые естественные контексты для такого да ну - это извинения и комплименты, ср.:

(26) А: Извини, Алеш, он, видимо, очень устал.

В: Да ну, Наташа, о чем ты говоришь.

[Юлий Райзман, Анатолий Гребнев. Частная жизнь, к/ф (1982)].

(27) [Буфетчица] A похорошела ть́́. Да-да, похоромела!

[Анна Веленстович] Oй, да ну!

[Леонид Быков и др. Аты-баты, шли солдаты, к/ф (1976)].

В данном случае Да ну! говорит следующее: собеседник ошибся в выборе иллокуции - нет настоящей причины, чтобы извиняться, комплименты по данному поводу говорящему не нужны, он только испытывает неловкость.

В определенном смысле этот класс семантически противоположен предыдущему: поскольку в случае извинения и комплимента говорящий бенефициант, он не только не испытывает к собеседнику отрицательных эмоций, как в (21)-(25), но может испытывать и положительные, - например что-то вроде смущения. Поэтому если говорить о мимике и жестикуляции, то именно в этих контекстах, прежде всего, конечно, в ответ на комплимент, случается улыбка и смущение («глаза вниз») - помимо «отвернуться» и «нахмурить брови» или маркеров отрицания для извинения: «махнуть рукой», «склонить голову набок», «пожать плечами».

Обратим внимание на еще один более редкий, но тоже характерный случай девалоризации, близкий к только что рассмотренным. Это девалоризация излишней вежливости собеседника. Отмена формальностей в обращении (ср. разрешение обращаться к себе не по званию или должности, как ваше благородие, а по имени-отчеству: Григорий Петрович; или использовать краткую форму имени: не Григорий, а Гриша) может производиться говорящим с помощью Да ну:

(28) [Рита] Товарищ полковник.

[Курбатов] Да ну... Тимур.

[Рита] Тимур Курбатович.

[Курбатов] Тимур.

[Валерий Тодоровский, Геннадий Островский. Мой сводный брат Франкенштейн, к/ф (2004)]

\section{4. Девалоризация оценочного суждения}

В этот класс употреблений попадают контексты, в которых собеседник дает негативную оценку ситуации Р. Эта оценка может быть связана с его страхом, предубеждениями, пессимистическими ожиданиями и подобным. Говорящий хочет 
убедить собеседника ее снять, внушая ему оптимизм и говоря что-то вроде: ‘это не так страшно, не так опасно, не думай, не сосредотачивайся на этом неприятном Р’ и т.д. Ср. (29)-(30):

(29) А: Организуем клумбу с самыми красивыми цвветами!

B: Ассигнований нет!

А: Да ну, я попрошу шоферов, они мне принесут. Из Крыма роз, с Карпат эдельвейсов.

[Алексей Мишурин и др. Королева бензоколонки, к/ф (1963)]

- Юшка, как твоя нога? -Да ну, фигня, - отмахнулась она. - Думали растяжение, оказалось - ушиб. Заживет как на собаке. [Дина Сабитова. Где нет зимы (2011)]

Круг русских квазисинонимов ${ }^{7}$ (типа Брось! Забудь! и подобных) выделяет этот тип $\partial а н y !$ из прочих употреблений и связывает его с полем каузации прекращения ситуации (более точно — continuous prohibitive, см. [Рахилина 2013]). Такое Да ну! может маркироваться даже интонационно: наряду с обычным для других типов девалоризации падающим тоном оно может сопровождаться высоким, который как бы специально акцентирует незначимость предыдущего высказывания. Что касается жестикуляции, то этот тип Да ну! маркируется целым кластером жестов, отражающих отрицательную оценку («нахмурить брови»), собственно девалоризацию («махнуть рукой»), несогласие и дистанцирование («склонить голову», «поднять плечи»).

Теперь рассмотрим жестовые параметры Да ну! в разных его вариантах подробHee.

\section{6. Жестикуляция и статистика}

\section{1. Жестовые параметры и их соотноиение}

Как мы помним, из 190 видеозаписей с Да ну! в МУРКО только в 78 фрагментах жесты говорящего были достаточно хорошо видны во время произнесения формулы. Такие фрагменты размечались по семантическим классам Да ну! и по шести жестовым параметрам - ручные и головные жесты, движение корпуса, глазное поведение, улыбка или смех и движение бровей.

После этого к выборке были последовательно применены алгоритмы Random forest, CART (Classification and Regression Tree) и Multiple Correspondence Analysis.

Мы использовали алгоритм Random forest, чтобы ранжировать жестовые параметры по тому, насколько каждый из них влияет на выбор значения зависимой переменной, - в нашем случае - семантического класса формулы. Полученный результат представлен на рисунке 2. Наибольшая зависимость от семантического

7 Хороших типологических коррелятов по параллельным корпусам для этого типа пока не найдено.

${ }^{8}$ Мы благодарим Г. А. Мороза за консультации по анализу данных. 


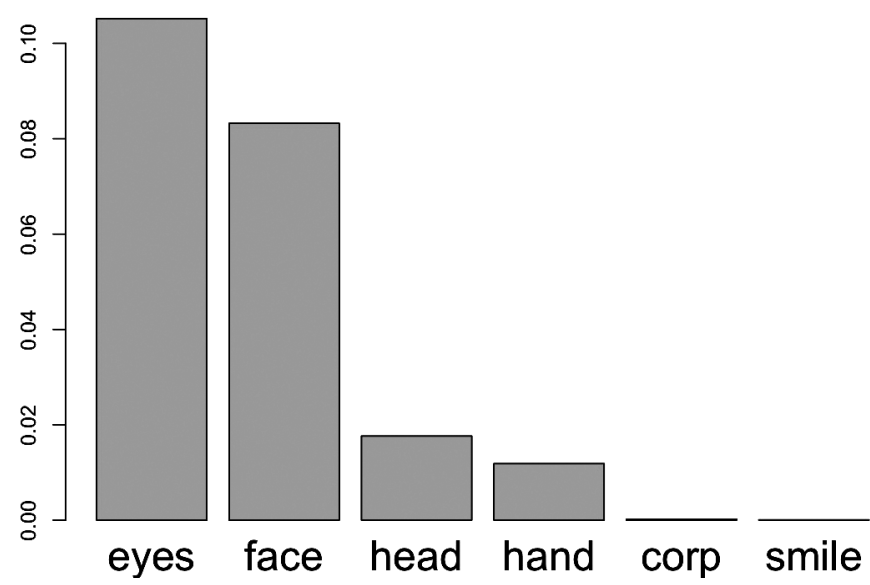

Рис. 2. Ранжирование жестовых параметров

класса обнаружилась у направления взгляда говорящего. Следом за ним идет движение бровей, далее - уже значительно менее существенные головные и ручные жесты. Движение корпуса и улыбка, согласно этим данным, с семантикой формулы связаны минимально.

Применение к нашему материалу еще одного алгоритма - CART дает возможность выявить существенную корреляцию значений жестовых параметров и выделенных значений Да ну!, так что с его помощью мы сможем для каждого параметра (направление взгляда, движение корпуса, рук и проч.) проследить, какие группы употреблений Да ну! им маркируются.

\section{1. Взгляд}

При разметке движения глаз мы пользовались системой из [Гришина 2017: 491]. В этой системе противопоставлено направление взгляда внутри зоны коммуникации (ЗК) и вне ее, так что в рамках одного жеста описываются исходное положение взгляда и итоговое. В нашей разметке добавилась новая разновидность -направления взгляда вне ЗК: взгляд вниз.

На основании взаимодействия двух параметров - направления взгляда и семантики формулы - было построено дерево классификации данных (рис. 3).

Как видно из левой ветви графа (node 2), для реакций на извинение, отказов и девалоризации оценочного суждения нет разметки взгляда. Она отсутствуетпо чисто техническим причинам: в этих клипах взгляд не виден.

Семантический класс реакции на комплимент прекрасно выделяется жестами «Внутри ЗК $\rightarrow>$ Опустить глаза» и «Взгляд вниз $\rightarrow$ Взгляд вниз» (node 4). Это довольно естественно, потому что для таких ситуаций характерен жест «потупиться», который выражает смущение.

Оставшиеся данные делятся следующим интересным образом. Да ну в значении девалоризации провинившегося собеседника сопровождается либо выходом взгляда 
a (apology) - реакция на извинение

c (compliment) - реакция на комплимент

da (disappointment) - досада на собеседника

$\mathrm{db}$ (disbelief) - неверие

e (encouragement) - девалоризация негативной оценки P ii.......... Внутри 3К $\rightarrow$ Внутри 3 К

iо..........Внутри ЗК $\rightarrow$ Выход

оi.........Вне ЗК $\rightarrow$ Вход

оо........Вне 3К $\rightarrow$ Вне 3К

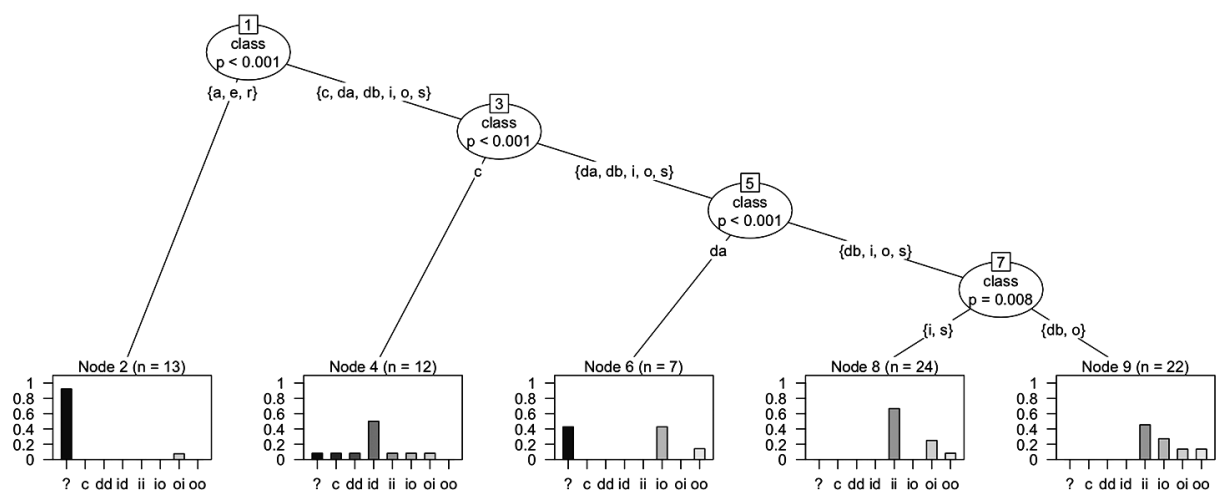

Рис. 3. Распределение значений параметра «взгляд» по группам употреблений Да ну!

из зоны коммуникации, либо пребыванием взгляда вне ее от начала и до конца реплики (node 6). Для удивления и производных от него иронических употреблений 9 , напротив, свойственно в первую очередь постоянное нахождение взгляда внутри ЗК либо также движение глаз из положения вне ЗК в сторону собеседника (node 8). В то же время объединенные в одну группу неверие и отказ разделить энтузиазм по поводу варианта X (см. 5.1) демонстрируют свойства как первого, так и второго: «Внутри ЗК $\rightarrow$ Внутри ЗК», «Внутри ЗК $\rightarrow$ Выход», «Вне ЗК $\rightarrow>$ Вход». По крайней мере, для класса неверия это вполне объяснимый результат, поскольку семантически оно как раз и представляет собой сочетание удивления и девалоризации.

Заметим, что, по Е.А. Гришиной, стационарное положение взгляда внутри ЗК свойственно репликам подтверждения, а любой переход (в зону коммуникации или из нее наружу) - негации. Наша выборка дает несколько другую картину. Неотрицательное высказывание - удивление - по-прежнему характеризуется комбинацией «Внутри ЗК -> Внутри ЗК», но достаточно часто маркируется и переходом взгляда в зону коммуникации. Отрицательное - девалоризация - сочетается и с выходом взгляда из ЗК, и с фиксированным взглядом в сторону, но не с переводом глаз в ЗК.

Таким образом, более значимым фактором для отрицательности Да ну! является финальное направление взгляда, а не наличие или отсутствие движения.

Отрицательная полярность - не единственный признак, который маркируется взглядом. Жест «потупить глаза» характеризует группу употреблений с девалоризацией комплимента, выделяя ее среди других девалоризаций, — в том числе девалоризации извинения (табл. 1).

${ }^{9}$ Интересно, что по смыслу ирония совпадает с неверием, но маркируется так же, как удивление, которое эта ирония имитирует. 
Направление взгляда при разных употреблениях Данн!

\begin{tabular}{|l|l|}
\hline Удивление (в том числе ироническое) & $\begin{array}{l}\text { (1) Внутри ЗК } \rightarrow \text { Внутри 3К } \\
\text { (2) Вне 3К }->\text { Вход }\end{array}$ \\
\hline Реакция на комплимент & Потупить глаза \\
\hline Девалоризация (кроме комплимента), неверие & $\begin{array}{l}\text { (1) Внутри 3К } \rightarrow \text { Выход } \\
\text { (2) Вне 3К } \rightarrow \text { Вне 3К }\end{array}$ \\
\hline
\end{tabular}

\section{3. Движение бровей}

Два лицевых жеста, встретившихся в выборке, — «нахмурить брови» и «поднять брови» - противопоставляют классы значений, содержащие компонент девалоризации, и удивление - единственный класс, который не содержит идеи отрицания. Как видно на рисунке 4, при удивлении брови часто подняты, но никогда не нахмурены; при девалоризации - бывают нахмурены, а подняты редко. Жест «поднять брови» в [Гришина 2017] отнесен к жестам дистанцирования, а «нахмуриться» - к эмфатическим [Гришина 2017: 457]. Именно эмфатические жесты коррелируют с контекстами, в которых присутствует отрицательная оценка (Гришина 2017: 458).

Мимика, таким образом, дублирует противопоставление, маркируемое интонационно, отделяя отрицательные употребления Да ну! от нейтральных.

a (apology) — реакция на извинение

c (compliment) - реакция на комплимент

da (disappointment) — досада на собеседника

$\mathrm{db}$ (disbelief) - неверие

e (encouragement) - девалоризация негативной оценки P

i (irony) - ирония (из удивления)

o (object) - девалоризация предложенного варианта

r (refusal) - отказ на предложение

s (surprise) - удивление bigeyes.........жест «расширить глаза» browsdown... жест «нахмурить брови» browsup........есет «поднять брови»

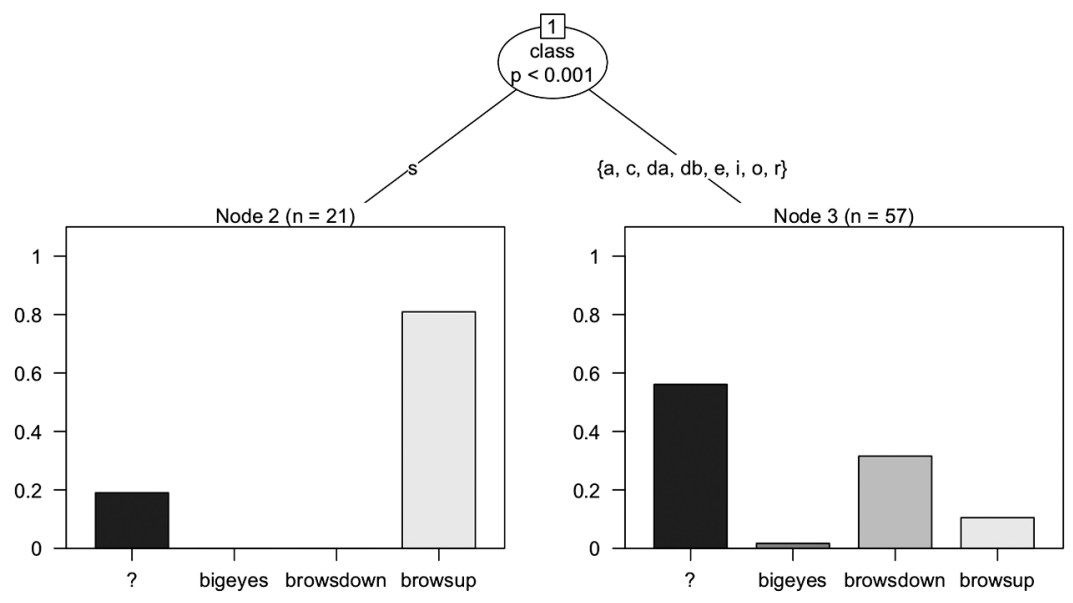

Рис. 4. Распределение параметра «движение бровей» по группам употреблений Да ну! 


\section{4. Голова}

Классы реакции на комплимент, девалоризации собеседника и отказа на предложение маркируются специальным головным жестом (рис. 5, node 2), в котором говорящий отворачивает голову в сторону и задерживает там на некоторое время, прежде чем повернуться обратно к собеседнику ${ }^{10}$. Жест «отвернуться от собеседника» упоминается в [Гришина 2017] в одном ряду с жестом «закрыть глаза», который рассматривается там как способ блокировать поступающую информацию [Гришина 2017: 510]. Такое толкование жеста подходит и для Да ну!, особенно в ответе на комплимент, потому что девалоризация речевого акта подразумевает, что говорящий не собирается слушать то, что начал говорить собеседник.

Жест «склонить голову набок» характеризует другую группу значений — классы реакции на извинение, неверия, иронии и девалоризации предложенного варианта (node 5). Он классифицируется как жест дистанцирования [Гришина 2017: 457]; жесты этого типа часто сопровождают контексты несогласия [Гришина 2017: 458].

Как оказалось, для классов удивления и девалоризации негативного суждения характерно отсутствие головных жестов (node 4) - должно быть, потому, что это единственные два типа употребления Да ну!, обладающие положительной тональностью.

a (apology) - реакция на извинение

c (compliment) - реакция на комплимент

da (disappointment) - досада на собеседника

$\mathrm{db}$ (disbelief) - неверие

e (encouragement) - девалоризация негативной оценки $\mathrm{P}$

i (irony) - ирония (из удивления)

o (object) - девалоризация предложенного варианта

r (refusal) - отказ на предложение

KG.......... жест «покачать головой» away......... жест «отвернуться»

back..........ест «качнуть головой назад»

down.......... жест «опустить голову»

nod......... жест «кивнуть»

none......... отсутствие головного жеста

tilt.........жест «склонить голову набок»

to_A.........есет «повернуть голову к собеседнику» turn. жест «повести головой в сторону»

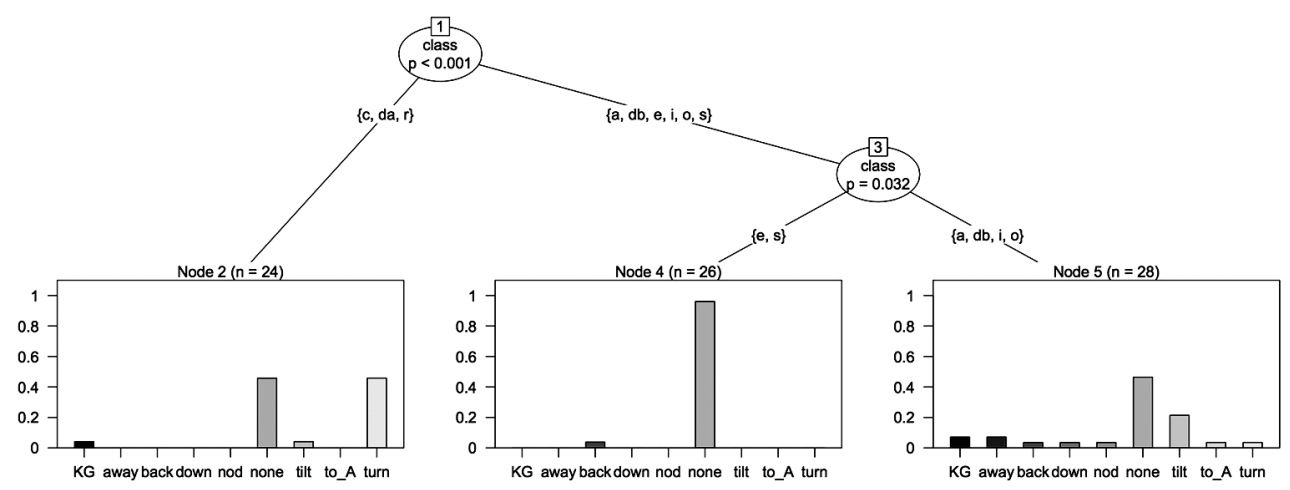

Рис. 5. Распределение параметра «движение головы» по группам употреблений Да ну!

${ }^{10}$ Иллюстрацию дает клип Мультимедийного корпуса, соответствующий следующему примеру: (А) [Пашка] Попо́зже-то въі́йдешь? [Катя] A для чего́? [Пашка] Да ну́уотвернутья от собеседника Ка́mя! A я́ отку́да зна́ю? Тоскли́во же одно́й-то! [Василий Шукшин. Живет такой парень, к/ф (1964)]. 
В результате жесты головы разбивают кластер значений девалоризации на три части. К первой относятся те, для которых более релевантно желание говорящего прекратить обсуждение вопроса, - а именно реакция на комплимент, девалоризация собеседника и отказ. Это проявляется в виде жеста «отвернуться от собеседника».

Ко второй относятся те, в которых более существен компонент несогласия. К ним относятся неверие, ирония, девалоризация предложенного варианта и извинение. Они маркируются жестом «склонить голову набок».

К третьей относится «мягкая» девалоризация - девалоризация негативного суждения, которая в данном случае примыкает к удивлению и не маркируется головными жестами.

\section{5. Руки}

Единственным ручным жестом, который присутствовал в выборке, был жест «махнуть рукой» ${ }^{11}$. Классы значений Да ну! разделились на три группы по тому, насколько этот жест им свойствен (рис. 6). Больше всего он встречался при

a (apology) - реакция на извинение

c (compliment) - реакция на комплимент

da (disappointment) - досада на собеседника

$\mathrm{db}$ (disbelief) - неверие

e (encouragement) - девалоризация негативной оценки P

i (irony) - ирония (из удивления)

o (object) - девалоризация предложенного ва-

рианта

r (refusal) - отказ на предложение

$\mathrm{s}$ (surprise) - удивление hands_hips.......... жест «руки в боки» wave 1 .......... жест «махнуть рукой» wave $2 \ldots . . . . .$. жест «взмахнуть двумя руками»

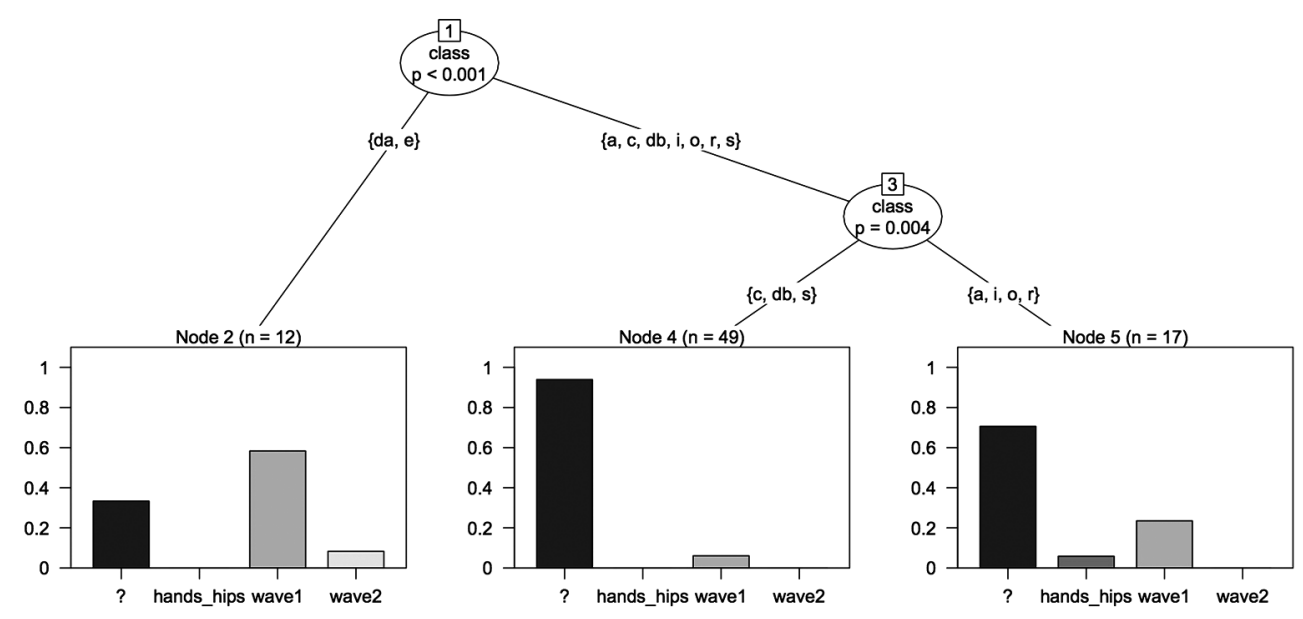

Рис. 6. Распределение параметра «ручные жесты» по группам употреблений Да ну!

11 Один раз, в контексте, где формула была употреблена в значении девалоризации негативного суждения, встретилась его разновидность, где то же движение было выполнено двумя руками. 
девалоризации собеседника или негативного оценочного суждения (node 2). Менее характерен он оказался для ответа на извинение, девалоризации предложенного варианта или отказа (node 5) и, наконец, практически не появлялся при удивлении, неверии или реакции на комплимент (node 4) (табл. 2).

Движение руки при разных употреблениях Дану!

\begin{tabular}{|l|l|}
\hline $\begin{array}{l}\text { Девалоризация собеседника; девалоризация негативного оце- } \\
\text { ночного суждения }\end{array}$ & «Махнуть рукой» \\
\hline $\begin{array}{l}\text { Отказ, девалоризация варианта, } \\
\text { ответ на извинение }\end{array}$ & «Махнуть рукой» \\
\hline Удивление, неверие, реакция на комплимент & «Махнуть рукой» \\
\hline
\end{tabular}

Если считать, что жест «махнуть рукой» действительно родствен прощальному жесту и имеет семантику 'неважно', бог с ним', получившаяся градация приобретает смысл: с одной стороны оказываются классы «чистой» девалоризации, а с другой - удивление, которое исключает идею незначительности стимула. Именно поэтому классы удивления и недоверия в данном случае не противопоставлены, как в интонации, а демонстрируют сходное поведение.

\subsection{Kopnyc}

У движения корпуса также обнаружилась некоторая зависимость от семантики Да ну! (рис. 7). Для значения удивления характерны жесты «корпус вперед» и «корпус назад» (node 5), а классы реакции на извинение и неверия объединяет сочетаемость с жестом «пожать плечами» (node 4).

\subsection{Multiple Correspondence Analysis}

Применение алгоритма МСА позволило нам визуально оценить близость выделенных нами групп употреблений Да ну! на основании свойственных им жестовых параметров. На рисунке 8 видны три основные семантические зоны - удивление, неверие и класс девалоризаций, которые, если рассматривать соответствующую им жестикуляцию статистически, оказываются практически тождественны. Классу девалоризаций максимально противопоставлено удивление: оно отстоит от него пространственно, с пренебрежимо малой долей пересечения. Исключение составляет девалоризация негативного оценочного суждения (см. 5.4), которая выделяется из гомогенного класса других девалоризаций. Действительно, на представленном рисунке она существенно пересекается с удивлением, демонстрируя, что в таких употреблениях одновременно с отрицательным компонентом содержится некоторая позитивная задача. Тем временем значения жестовых переменных, которые коррелируют с классом неверия, не сосредоточены в одном кластере, а распространяются достаточно широко; так, он не только семантически, но и жестово объединяет удивление и девалоризацию. 
a (apology) - реакция на извинение c (compliment) - реакция на комплимент da (disappointment) - досада на собеседника $\mathrm{db}$ (disbelief) - неверие

e (encouragement) - девалоризация негативной оценки $\mathrm{P}$

i (irony) - ирония (из удивления)

o (object) - девалоризация предложенного варианта

r (refusal) - отказ на предложение

$\mathrm{s}$ (surprise) - удивление back. away.... none. shrug. slouch жест «отклонить корпус назад» жест «повести корпус вперед» ...отсутствие движения корпусом жест «пожать плечами» жест «сгорбиться»

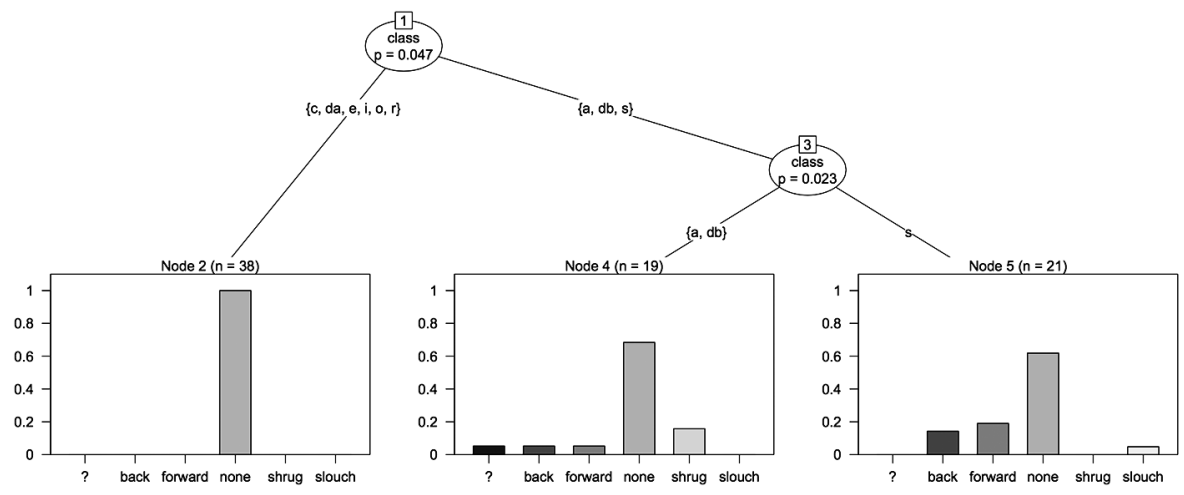

Рис. 7. Распределение параметра «движение корпуса» по группам употреблений Да ну

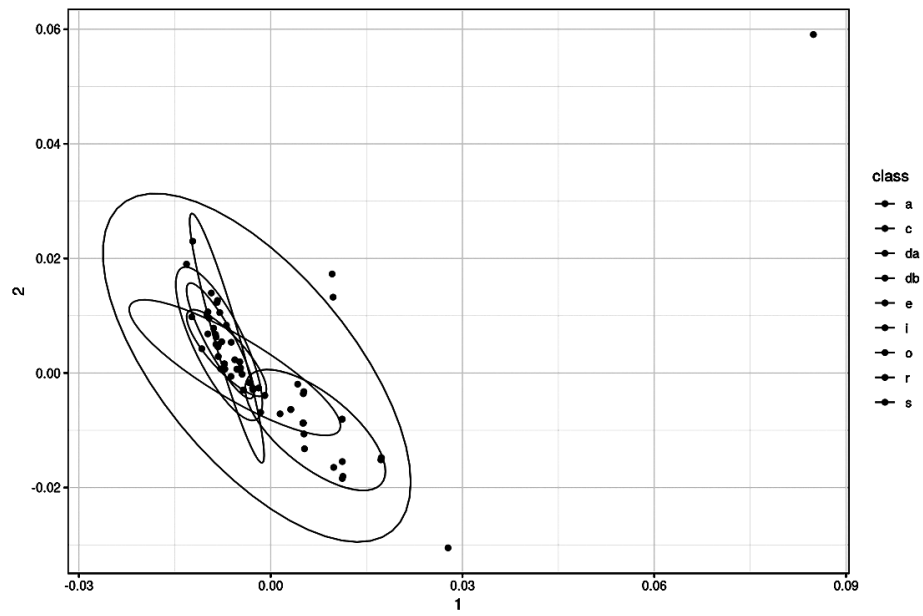

Рис. 8. Соотношение групп употреблений Да ну! с точки зрения жестового маркирования

\section{7. Заключение}

Настоящее исследование мы считаем пилотным для построения специализированной базы данных по дискурсивным формулам как особому типу конструкций в рамках проекта «Русский конструктикон». Пример Да ну! демонстрирует специфику этих единиц и выявляет информацию, необходимую для их полного описания. 
В нашей базе несколько полей. Проведенная работа позволяет оправдать их присутствие и заполнить их на материале Да ну!

1. Как языковая единица, или вход в базу, дискурсивная формула отличается от обычной конструкции и просто однословной предикатной единицы тем, что не содержит переменных — и в этом отношении кажется слишком простой.

На самом деле, как видно из только что представленного описания, важнейшей переменной для них является тип предшествующего контекста, который стимулирует формулу как ответную реплику говорящего: разные дискурсивные формулы реагируют на разные типы иллокуций, и они же структурируют значения многозначных формул. Действительно, если на вход Да ну! в значении удивления поступает утверждение, содержащее новую информацию, то на вход девалоризационного кластера, в зависимости от подтипа, поступают просьбы, приглашения, комплименты, извинения, опасения и проч. Мена стимула (который можно считать лингвистическим аналогом философского понятия речевого акта ${ }^{12}$ ) приводит к мене значения формулы.

2. Как мы видели на примере Да ну!, частотные формулы могут быть многозначны. У Да ну! мы выделили пять значений: удивление-доверие, удивление-неверие, девалоризация с оценкой собеседника, девалоризация речевого акта и девалоризация оценочного суждения. Можно ожидать, что полученные при описании Да ну! классы и подклассы употреблений (и соответствующие им семантические поме$\boldsymbol{m b l}$ ) будут востребованы при дальнейшей классификации всего списка формул ${ }^{13}$.

3. Значения, представленные в кластере Да ну!, имеют квазисинонимы, - в том числе среди дискурсивных формул, ср., например, Да ладно! как маркер удивления-неверия.

4. Типологические корреляты дискурсивных формул расширяют наше представление и об источниках конструкционализации, и о дробности противопоставлений внутри реплик-реакций определенного типа. Материал английского показывает, что для некоторых значений прямых аналогов дискурсивных формул (то есть изолированных неоднословных реплик-реакций в ответ на те же стимулы) в каких-то языках может и не быть. В таком случае материал параллельных корпусов помогает найти их лексические или грамматические корреляты, расширяя наше представление о лексико-грамматической и семантико-синтаксической интеграции в языке.

5. Мы показали, что все употребления Да ну! восходят к композициональной структуре, «собранной» из двух частиц (да и ну) и имеющей семантику интенсификации ускорения. По нашему мнению, источники конструкционализации дискурсивных формул не бывают случайными, а соответствующие им процессы, приводящие к потере композициональности, должны быть регулярны, - поэтому они чрезвычайно интересны с теоретической и типологической точек зрения. Следовательно, исходная для формулы структура тоже должна отражаться в базе.

12 Уделить достаточное внимание проблематике лингвистического и философского определения речевого акта, — и в том числе обзору работ на эту тему — в данной работе не представляется возможным. Этим вопросам будет посвящена отдельная готовящаяся нами публикация.

13 Процедура составления списка описана в [Пужаева и др. 2018]. 
6. Важнейший для этой работы сюжет, выделяющий дискурсивные формулы среди прочих конструкций, - это особый способ маркирования семантических противопоставлений для формул. Поскольку формулы дискурсивны, то, как мы видели на примере $\partial а н$ ну, они свойственны прежде всего разговорному языку и широко используют его преимущества: интонацию и жестикуляцию.

То, что в русском языке интонация служит для разрешения полисемии, хорошо известно - ср. пример с вообще в [Апресян 2004: 19] ${ }^{14}$, а также [Кодзасов 1993]. Наше исследование дает этому новые подтверждения: некоторые значения (группы значений) Да ну! отчетливо противопоставлены интонационно: 'удивление' (HL*) — ‘девалоризация’ (L*) — ‘девалоризация отрицательного суждения’ $\left(\mathrm{H}^{*} / \mathrm{L}^{*}\right)$.

7. Если интонационная тематика в целом достаточно традиционна, то обсуждение в этом контексте жсестикуляции, в особенности в этом контексте, - во многом достижение Е.А. Гришиной. Она одной из первых, по крайней мере для русского языка, показала, что жестикуляция релевантна для этой задачи, предоставила значительный языковой материал, который нас в этом убеждает, и создала метаязык (язык разметки МУРКО), который позволяет этот материал структурировать, - в частности в нашей базе данных. Дробная разметка в базе фиксирует отдельно движение глаз, махи руки, мимику, движение корпуса и проч.

8. Все сказанное суммирует таблица 3, представляющая предварительные результаты нашего анализа Да ну!

Центральной в этой таблице является информация о жестикуляции. Видно, что жестикуляция не дублирует интонацию - у каждого из этих несегментных средств, как показывает таблица, своя функция. Мелодический контур набрасывает так сказать «крупную сетку» на значения Да ну! Он противопоставляет неотрицательные (удивление) и отрицательные (девалоризация и неверие) реакции говорящего, особым образом маркируя своего рода промежуточный случай (девалоризацию отрицательного суждения). Жестикуляция эту классификацию подтверждает - и детализирует: таблица показывает, что значения разных параметров собираются в кластеры, которые маркируют несколько дополнительных значений: неверие, девалоризацию собеседника, ситуацию извинения и комплимента.Таким образом, жестовый материал горизонтальных строк независимо поддерживает семантические оппозиции, и это важный для нас вывод.

В свою очередь, столбцы таблицы 3 тоже подтверждают наши представления о структуре поля Да ну! Они свидетельствуют о непрерывности его семантического пространства. Действительно, каждый жестовый параметр как бы заполняет семантическую карту этого пространства, и в этом отношении они ведут себя так же, как ведет себя другой язык - английский, испанский, таджикский и проч., который по-своему структурирует определенную лексико-типологическую зону.

14 Пример Ю.Д. Апресяна показывает, как фразовая интонация противопоставляет значения слова вообще в предложениях Разжигать костры он $\downarrow$ вообще запрещал и Разжигать костры он вообще $\downarrow$ запрещал, [но <..>]. 
Да ну! как многозначная дискурсивная формула

\begin{tabular}{|c|c|c|c|c|c|c|c|c|c|}
\hline \multirow[b]{2}{*}{$\begin{array}{c}\text { Входной } \\
\text { речевой акт }\end{array}$} & \multirow[b]{2}{*}{ Значение Да ну } & \multirow{2}{*}{ 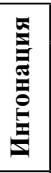 } & \multicolumn{5}{|c|}{ Жесты } & \multirow[b]{2}{*}{ Квазисинонимы } & \multirow[b]{2}{*}{ Переводы } \\
\hline & & & صิ & 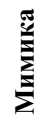 & 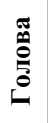 & فำ & 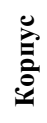 & & \\
\hline новость & удивление & & & & & & & $\begin{array}{l}\text { Неужели? } \\
\text { Ну и ну! } \\
\text { Надо же! } \\
\text { Да ты что! } \\
\text { Не может быть! }\end{array}$ & $\begin{array}{l}\text { Oh, my! Oh, } \\
\text { really? No way! } \\
\text { Does it? You } \\
\text { don't say? } \\
+ \text { tag questions }\end{array}$ \\
\hline новость & ирония & & & & & & & $\begin{array}{l}\text { Неужели? } \\
\text { Надо же! } \\
\text { Да ты что! } \\
\text { Да ладно! }\end{array}$ & tag questions \\
\hline извинение & $\begin{array}{l}\text { девалоризация } \\
\text { речевого акта }\end{array}$ & & & & & & & $\begin{array}{l}\text { Да ладно! } \\
\text { Что ты! }\end{array}$ & well, now! \\
\hline новость & неверие & & & & & & & $\begin{array}{l}\text { Да ладно! } \\
\text { Не может быть! } \\
\text { Никогда не по- } \\
\text { верю! }\end{array}$ & $\begin{array}{l}\text { No! Really? } \\
\text { Come on! Please, } \\
\text {... }\end{array}$ \\
\hline комплимент & $\begin{array}{l}\text { девалоризация } \\
\text { речевого акта }\end{array}$ & & & & & & & Да ладно (тебе)! & - \\
\hline предложение & \begin{tabular}{|l|} 
отказ + девало- \\
ризация собесед- \\
ника \\
\end{tabular} & & & & & & & Ну его! & No! Really? \\
\hline $\begin{array}{l}\text { невыполнен- } \\
\text { ная просьба }\end{array}$ & $\begin{array}{l}\text { девалоризация } \\
\text { собеседника }\end{array}$ & & & & & & & $\begin{array}{l}\text { Да ну тебя! Иди } \\
\text { к черту! } \\
\text { Эх ты! }\end{array}$ & - \\
\hline $\begin{array}{l}\text { негативное } \\
\text { оценочное } \\
\text { суждение }\end{array}$ & $\begin{array}{l}\text { девалоризация } \\
\text { суждения }\end{array}$ & & & & & & & $\begin{array}{l}\text { Чего ты! Да лад- } \\
\text { но (тебе)! }\end{array}$ & Come \\
\hline
\end{tabular}

\section{Литература}

Апресян Ю.Д. Дейксис в лексике и грамматике и наивная модель мира // Семиотика и информатика. 1986. Вып. 28. С. 5-33.

Апресян Ю.Д., Богуславская О.Ю., Левонтина И. Б., Урысон Е.В., Гловинская М.Я., Крылова Т.В. Новый объяснительный словарь синонимов русского языка. Первый выпуск. 2-е изд. М., 1999.

Гришина E. A. К вопросу о соотношении слова и жеста (вокальный жест О в устной речи) // Компьютерная лингвистика и интеллектуальные технологии (по материалам ежегодной Международной конференции «Диалог 2009»). Вып. 8 (15). М., 2009. C. 80-90.

Гришина E.A. Вокальный жест А в устной речи // Компьютерная лингвистика и интеллектуальные технологии (по материалам ежегодной Международной конференции «Диалог 2010»). Вып. 9 (16). М., 2010. С. 102-112.

Гришина E. A. Русская жестикуляция с лингвистической точки зрения (корпусные исследования). М.: Языки русской культуры, 2017. С. 217. 
Дурягин П. В., Рахилина Е.В. Просодические средства маркирования дискурсивной формулы $\partial а$ ну // Тезисы VI Международной научной конференции «Культура русской речи» (21-23 февраля 2019 года) URL: https://drive.google.com/file/d/1eXD ZzrSpHqhYU3fPqVk0KMSPGnKkTXuM/view (дата обращения: 06.07.2019).

Касаткин Л.Л. Русская интонация: тональные контуры // Проблемы фонетики. Вып. V. / Отв. ред. Р. Ф. Касаткина. М., 2007.

Князев С. В., Пожарицкая С. К. Современный русский литературный язык: Фонетика, орфоэпия, графика и орфография. М.: Академический Проект; Гаудеамус, 2012.

Кодзасов С.В. Интонация предложений с дискурсными словами // Путеводитель по дискурсивным словам русского языка. М., 1993.

Национальный корпус русского языка. URL: http://www.ruscorpora.ru/.

Пужаева С.Ю., Герасименко Е.А., Захарова Е.С., Рахилина Е.В. Автоматическое извлечение дискурсивных формул из текстов на русском языке // Вестник НГУ. Серия: Лингвистика и межкультурная коммуникация. 2018. № 2.

Рахилина Е.В. Кондуктор, нажми на тормоза... // Компьютерная лингвистика и интеллектуальные технологии: По материалам ежегодной Международной конференции «Диалог» (Бекасово, 29 мая - 2 июня 2013 г.): в 2 т. Т. 1: Основная программа конференции. Вып. 12 (19). М., 2013. С. 665-673.

Рахилина Е. В., Кузнецова Ю.Л. Грамматика конструкций: теории, сторонники, близкие идеи // Лингвистика конструкций / ред. Е.В. Рахилина. М.: Азбуковник. 2010. C. $18-79$.

Рахилина E. В., Плунгян В.A. Из корпусных наблюдений над лексикой: о семантической эволюции и «лексических маркерах» // La lettre et l'esprit - entrelangue et culture: Études à la mémoire de Jean Breuillard. Vol. LXXXIII. Iss. 2-3. P.: Institut d'études slaves, 2012. P. 499-533.

Рахилина Е.В., Резникова Т.И. Фреймовый подход к лексической типологии // Вопросы языкознания. 2013. №2. С. 3-31.

Шаронов И.А. Коммуникативы как функциональный класс и как объект лексикографического описания // Русистика сегодня. 1996. № 2. С. 89-112.

Шаронов И. А. Коммуникативы и методы их описания // Компьютерная лингвистика и интеллектуальные технологии (по материалам ежегодной Международной конференции «Диалог 2009»). Вып. 8 (15). М., 2009. С. 543-547.

Янко T.E. Интонационные стратегии русской речи в сопоставительном контексте. М., 2008.

Aijmer K. Conversational Routines in English. Harlow, 1996.

Bressem J. and Müller C. "The family of Away gestures: Negation, refusal, and negative assessment," in Body - Language - Communication. An International Handbook on Multimodality in Human Interaction (Handbooks of Linguistics and Communication Science 38.2). Berlin/Boston: De Gruyter Mouton, 2014. P. 1592-1604.

Coulmas F. (ed.). Conversational routine. The Hague: Mouton, 1981.

Fillmore C.J. Remarks on contrastive pragmatics // Contrastive linguistics: Prospects and problems. 1984. P. 101. 
Fillmore C.J., Kay P., O'Connor M.C. Regularity and idiomaticity in grammatical constructions: The case of let alone // Language. 1988. Sep. 1. pp. 501-538.

Janda L. A., Lyashevskaya O., Nesset T., Rakhilina E. \& Tyers F. M. A Constructicon for Russian: Filling in the Gaps. B. Lyngfelt, T. T. Torrent, L. Borin \& K. H. Ohara (eds.). Constructicography: Constructicon development across languages. (forthc.)

Kobozeva I., Ivanova O., Zakharov L. Towards multimodal modelling of verification discourse markers in russian dialog. // Вестник Московского университета. Серия 9: Филология, 2019, no. 1. pp. 36-49.

Traugott E. C., Trousdale G. Constructionalization and Constructional Changes. Oxford: Oxford University Press, 2013.

\author{
${ }^{1}$ P.A. Bychkova, ${ }^{1,2}$ E.V. Rakhilina, ${ }^{1}$ E.A. Slepak \\ ${ }^{1}$ National Research University Higher School of Economics \\ ${ }^{2}$ Vinogradov Russian Language Institute, Russian Academy of Sciences \\ (Russia, Moscow) \\ polyatomson@gmail.com,rakhilina@gmail.com,janenikel16@gmail.com
}

\title{
DISCOURSE FORMULAE, POLYSEMY AND GESTURE MARKING
}

The paper suggests a discussion of semantic marking for specific multiword colloquial constructions, discourse formulae. This type of linguistic unit is used in dialogical speech as isolated remark in response to the utterance of another member of conversation. The properties of discourse formulae include entire fixedness and non-transparent form on one hand and, on the other hand, the ability to develop various illocutionary meanings. In the paper it is argued that in case of polysemy not only the prosody allows to distinguish the intention of the speaker but also the gesture. The role of gesture for disambiguation of formulae meanings is illustrated by the case of Russian highly polysemantic discourse formula $D a n u$ !. The paper covers the classification of contexts of its use which reveals five major meanings of $D a n u !$ : expression of surprise, expression of disbelief, devaluation of the interlocutor, devaluation of the interlocutor's apology or compliment and "positive" devaluation of the interlocutor's concern. The process of historical development of the meanings is also briefly highlighted. A quantitative analysis of gesture most commonly accompanying $\mathrm{Da} n u$ ! in each of the five meanings is further conducted, with the data retrieved from Multimodal Russian Corpus and then manually annotated. The analysis shows correlation between the identified meanings and particular gesture sets. The distribution of the gesture might allow to discover adjacency of the meanings of the formula and also provide a deeper insight into the semantics of the gesture involved.

Keywords: Construction grammar, discourse formulae, gesture, polysemy, pragmatics 


\section{References}

Aijmer K. Conversational Routines in English. Harlow, 1996.

Apresyan Yu.D. [Deixis in lexicon and grammar and naïve model of the world]. Semiotika i informatika. 1986. no. 28, pp. 5-33. (in Russ.)

Apresyan Yu.D., Boguslavskaya O.Yu., Levontina I.B., Uryson E.V., Glovinskaya M.Ya., Krylova T.V. Novyi ob"yasnitel'nyi slovar' sinonimov russkogo yazyka [New Explanatory Dictionary of Russian Synonyms]. Issue 1, 2 ed. Moscow, 1999. (in Russ.)

Bressem J. and Müller C. "The family of Away gestures: Negation, refusal, and negative assessment". Body - Language - Communication. An International Handbook on Multimodality in Human Interaction (Handbooks of Linguistics and Communication Science 38.2). Berlin/Boston: De Gruyter Mouton, 2014. pp. 1592-1604.

Coulmas F. (ed.) Conversational routine. The Hague: Mouton, 1981.

Duryagin P.V., Rakhilina E.V. [Prosodic means for marking of discourse formula da nu]. Tezisy VI Mezhdunarodnoi nauchnoi konferentsii "Kul'tura russkoi rechi" [Abstracts of the $6^{\text {th }}$ International scientific conference "Russian linguistic culture" (February 21-23, 2019)]. Available at: https://drive.google.com/file/d/1eXDZzrSpHqhY U3fPqVk0KMSPGnKkTXuM/view (access date: 06.07.2019).

Fillmore C. J. Remarks on contrastive pragmatics // Contrastive linguistics: Prospects and problems. 1984. P. 101.

Fillmore C. J., Kay P., O'Connor M.C. Regularity and idiomaticity in grammatical constructions: The case of let alone // Language. 1988. Sep 1. pp. 501-538.

Grishina E.A. [On the question of word-gesture relationship (vocal gesture $\mathrm{O}$ in conversational speech)] // Komp'yuternaya lingvistika i intellektual'nye tekhnologii (po materialam ezhegodnoi Mezhdunarodnoi konferentsii "Dialog 2009") [Computational Linguistics and Intellectual Technologies (Annual International Conference "Dialogue 2009"], no. 8 (15). Moscow, RSGU Publ., 2009. pp. 80-90. (in Russ.)

Grishina, E. A. [Vocal gesture A in conversational speech] // Komp'yuternaya lingvistika i intellektual'nye tekhnologii (po materialam ezhegodnoi Mezhdunarodnoi konferentsii “Dialog 2010") [Computational Linguistics and Intellectual Technologies (Annual International Conference "Dialogue 2010"], no. 9 (16). Moscow, RSGU Publ., 2010, pp. 102-112 (in Russ.)

Grishina E. A. Russkaya zhestikulyatsiya s lingvisticheskoi tochki zreniya. Korpusnye issledovaniya [Russian gestures from a linguistic perspective. A collection of corpus studies]. Moscow: YaSK Publishing House; Yazyki Slavyanskoi Kul'tury, 2017 (in Russ.)

Janda L. A., Lyashevskaya O., Nesset T., Rakhilina E. \& Tyers F.M. A Constructicon for Russian: Filling in the Gaps. B. Lyngfelt, T. T. Torrent, L. Borin \& K. H. Ohara (eds.). Constructicography: Constructicon development across languages. (forthc.)

Kasatkin L. L. [Russian prosody: pitch contours]. Problemy fonetiki [Issues in phonetics]. Iss. 5. R. F. Kasatkina (ed.). Moscow, 2007 (in Russ.) 
Knyazev S. V., Pozharitskaya S. K. Sovremennyi russkii literaturnyi yazyk: Fonetika, orfoepiya, grafika i orfografiya [Modern Russian: Phonetics, orthoepy and orthography]. Moscow: Akademicheskii Proekt Publ.; Gaudeamus, 2012 (in Russ.)

Kobozeva I., Ivanova O., Zakharov L. Towards multimodal modelling of verification discourse markers in russian dialog. Vestnik Moskovskogo universiteta. Seriya 9: Filologiya, 2019. no. 1. pp. 36-49.

Kodzasov S. V. [The intonation of the sentences containing discourse words]. Putevoditel' po diskursivnym slovam russkogo yazyka [Guide to the discursive words of the Russian language]. Moscow, 1993. pp. 182-204 (in Russ.)

Puzhaeva Svetlana Yu., Gerasimenko Ekaterina A., Zakharova Elena S., Rakhilina Ekaterina V. [Automatic Extraction of Formulaic Expressions from Russian Texts]. Vestnik NGU. Seriya: Lingvistika i mezhkul'turnaya kommunikatsiya. [Vestnik NSU. Series: Linguistics and Intercultural Communication], 2018, vol. 16, no. 2, pp. 5-18. (in Russ.)

Rakhilina E.V. [Conductor, press the brake...] Komp'yuternaya lingvistika $i$ intellektual'nye tekhnologii (po materialam ezhegodnoi Mezhdunarodnoi konferentsii “Dialog 2013") [Computational Linguistics and Intellectual Technologies (Annual International Conference "Dialogue 2013”], no. 12 (19): In 2 vol. Vol. 1. Moscow, RSGU Publ., 2013, pp. 665-673 (in Russ.)

Rakhilina E. V., Kuznetsova Yu.L. [Construction Grammar: Theory, followers, similar ideas]. Lingvistika konstruktsii [Linguistics of constructions]. Rakhilina E. V. (ed.) Moscow: Azbukovnik Publ., 2010, pp. 18-79. (in Russ.)

Rakhilina E. V., Plungyan V.A. [Some corpus observations of lexicon: semantic evolution and "lexic markers"]. La lettre et l'esprit — entrelangue et culture: Études à la mémoire de Jean Breuillard. Vol. LXXXIII. Iss. 2-3. Paris, Institut d'études slaves, 2012, pp. 499-533. (in Russ.)

Rakhilina E. V., Reznikova T.I. [Frame approach to the lexical typology]. Voprosy Jazykoznanija [Topics in the study of language], 2013, no. 2, pp. 3-31. (in Russ.)

Russian National Corpus. URL: http://www.ruscorpora.ru/.

Sharonov I. A. [Communicatives as a functional class and a subject for lexicographic description]. Rusistika segodnya, 1996, no. 2, pp. 89-112. (in Russ.)

Sharonov I.A. [Communicatives and methods of their characterization]. Komp'yuternaya lingvistika i intellektual'nye tekhnologii (po materialam ezhegodnoi Mezhdunarodnoi konferentsii "Dialog 2009") [Computational Linguistics and Intellectual Technologies (Annual International Conference "Dialogue 2009”], no. 8 (15). Moscow, 2009. pp. 543-547. (in Russ.)

Traugott E.C., Trousdale G. Constructionalization and Constructional Changes. Oxford: Oxford University Press, 2013.

Yanko T. E. Intonatsionnye strategii russkoi rechi v sopostavitel'nom kontekste [Intonational strategies of Russian speech in comparative context]. Moscow, 2008. (in Russ.) 